\title{
KETAHANAN PANGAN RUMAH TANGGA BALITA 0-59 BULAN DI DESA PRIORITAS STUNTING
}

\author{
Nina Fentiana ${ }^{1}$, Daniel Ginting'2, Zuhairiah ${ }^{3}$ \\ 1,2,3 Universitas Sari Mutiara Indonesia \\ Email: fentiana.nina@gmail.com \\ DOI : $\underline{10.24252 / \text { kesehatan.v12i1.7847 }}$
}

\begin{abstract}
Abstrak
Data Pemantauan Status Gizi (PSG) selama tiga tahun terakhir mencatat bahwa prevalensi stunting mengalami peningkatan dari tahun 2016 yaitu 27,5\% menjadi 29,6\% pada tahun 2017. Prevalensi stunting di Sumatera Utara tahun 2017 (Data PSG) adalah 28,4\%. Artinya Sumatera Utara masih dalam kondisi bermasalah kesehatan masyarakat. Prevalensi stunting tertinggi di Sumatera Utara tersebar di 4 Kabupaten/Kota yaitu Langkat, Padang Lawas, Nias Utara dan Gunung Sitoli. Langkat adalah kabupaten dengan prevalensi stunting tertinggi yaitu 54.961 jiwa pada tahun 2013 atau sekitar 55,48\%. Guna menurunkan prevalensi stunting di bawah $25 \%$, pemerintah telah menetapkan 160 Kabupaten/kota prioritas dengan masing-masing 10 desa untuk penanganan stunting. Banyak faktor yang menyebabkan stunting pada balita, namun karena balita sangat tergantung pada ibu/keluarga maka kondisi keluarga dan lingkungan yang mempengaruhi keluarga akan berdampak pada status gizinya. Oleh karena itu perlu untuk mengkaji bagaimana ketahanan pangan rumah tangga Balita 0-59 bulan di desa Secanggang sebagai desa priorotas stunting. Penelitian menggunakan pendekatan cross sectional yang dilakukan di Desa Secanggang Kecamatan Secanggang Kabupaten Langkat dengan jumlah balita 0-59 dengan jumlah sampel adalah 45 orang. Data stunting diperoleh menggunakan indikator TB/U dan ketahanan pangan diukur menggunakan USHFSS. Hasil uji chi square menunjukkan ketahanan pangan RT memiliki hubungan yang signifikans dengan kejadian stunting pada balita 0-59 bulan $(\mathrm{p}=0,017)$. Sebanyak 15 balita stunting $(60,0 \%)$ ditemukan pada rumah tangga dengan kategori ketahanan pangan yang tidak aman pangan. Penelitian menyimpulkan bahwa ada hubungan yang signifikans antara ketahanan pangan rumah tangga dengan kejadian stunting pada balita 0-59 bulan
\end{abstract}

\section{Kata Kunci: Pendek, Prioritas, Secanggang}

\begin{abstract}
Nutritional Status Monitoring Data (PSG) over the past three years noted that the prevalence of stunting has increased from 2016 at 27.5\% to 29.6\% in 2017. The stunting prevalence in North Sumatra in 2017 (PSG Data) is $28.4 \%$. This means that North Sumatra is still in a state of public health problems. The highest stunting prevalence in North Sumatra is spread in 4 districts / cities, namely Langkat, Padang Lawas, North Nias and Gunung Sitoli. Langkat is the district with the highest prevalence of stunting, which was 54,961 people in 2013 or around 55.48\%. In order to reduce stunting prevalence to below $25 \%$, the government has set 160 priority districts / cities with 10 villages each for stunting treatment. Many factors cause stunting in infants, but because toddlers are very dependent on mother / family, family and environmental conditions that affect the family will have an impact on their nutritional status. Therefore it is necessary to examine how food security for under-five households in 0-59 months in
\end{abstract}


the village of Secanggang as a priority village of stunting. The study used a cross sectional approach conducted in Secanggang Village, Secanggang Sub district, Langkat District with a number of children from 0-59 with a total sample of 45 people. Stunting data were obtained using the TB / U indicator and food security was measured using USHFSS. The chi square test results showed that RT food security had a significant relationship with the incidence of stunting in infants $0-59$ months $(p=0.017)$. A total of 15 stunting toddlers $(60.0 \%)$ were found in households in the category of food insecurity. The study concluded that there was a significant relationship between household food security and the incidence of stunting in infants 0-59 months.

Keywords: Priority; Secanggang

\section{PENDAHULUAN}

Identifikasi stunting dilakukan dengan membandingkan tinggi anak dengan standar tinggi anak pada populasi normal sesuai dengan usia dan jenis kelamin yang sama. Anak digolongkan stunting jika tingginya berada dibawah -2 SD dari standar WHO. South East Asean Nutrition Survey (SEANUTS) pada tahun 2010-2011 melaporkan Indonesia sebagai negara dengan jumlah balita stunting terbesar diatas Malaysia, Thailand dan Vietnam (Trihono, 2015). Prevalensi stunting secara nasional di Indonesia mengalami peningkatan dari 35,6\% tahun 2010 menjadi 37,2\% tahun 2013. Prevalensi stunting pada balita di Indonesia terus meningkat, dari 18,0\% tahun 2007 (Riskesdas, 2007), 17,1\% di tahun 2010 (Riskesdas, 2010) dan naik menjadi 19,2\% di tahun 2013 (Riskesdas, 2013). Data Pemantauan Status Gizi (PSG) selama tiga tahun terakhir mencatat bahwa prevalensi stunting mengalami peningkatan dari tahun 2016 yaitu 27,5\% menjadi 29,6\% pada tahun 2017 (PSG, 2017).

Stunting dianggap menjadi masalah kesehatan masyarakat kategori kronis bila prevalensinya sebesar $\geq 20 \%$. Menurut data Riskesdas ada 14 propinsi di Indonesia yang stunting tergolong masalah kesehatan masyarakat berat dan 15 propinsi tergolong serius dan salah satunya adalah Propinsi Sumatera Utara. Prevalensi stunting di Sumatera Utara tahun 2017 (Data PSG) adalah 28,4\%. Artinya Sumatera Utara masih dalam kondisi bermasalah kesehatan masyarakat.

Prevalensi stunting tertinggi di Sumatera Utara tersebar di 4 Kabupaten/Kota yaitu Langkat, Padang Lawas, Nias Utara dan Gunung Sitoli. Langkat adalah kabupaten dengan prevalensi stunting tertinggi yaitu 54.961 jiwa pada tahun 2013 atau sekitar 55,48\% dibandingkan dengan Padang Lawas yang prevalensi stuntingnya 54,86\%, Nias Utara 54,83\% dan Gunung Sitoli 52,32\% (Tim Nasional Percepatan Kemiskinan, 2018).

Guna menurunkan prevalensi stunting dibawah 25\%, pemerintah telah menetapkan 160 Kabupaten/kota prioritas dengan masing-masing 10 desa untuk penanganan stunting. Langkat adalah salah satu kabupaten prioritas penanganan stunting di Sumatera Utara. Hal ini karena selain prevalensi stunting yang tinggi juga karena jumlah penduduk kabupaten ini paling banyak diantara 3 kabupaten prioritas lainnya dan kemampuan ekonominya rendah. Tahun 2016 jumlah penduduk kabupaten langkat 1.019,24 ribu jiwa dengan jumlah penduduk miskin 115,79 ribu jiwa dan tingkat kemiskinan 11,36\%. Secanggang adalah salah satu dari 10 desa yang menjadi prioritas penanganan stunting dikabupaten langkat. Data Dinas Kesehatan 
melaporkan ada 48 Kasus stunting pada Maret 2018 yang tersebar di Desa Secanggang, Desa Kebun Kelapa, Pematang Serai, Padang Tulang, Paluh Manis, Securai Utara dan Selatan serta Perlis (Menteri dalam Negeri RI, 2018).

Balita stunting akan terhambat pertumbuhan dan perkembangan dan risiko menderita penyakit tidak menular dimasa dewasa nanti, dan bila anak tumbuh menjadi ibu akan melahirkan anak yang juga berisiko stunting. Banyak faktor yang menyebabkan stunting pada balita, namun karena balita sangat tergantung pada ibu/keluarga maka kondisi keluarga dan lingkungan yang mempengaruhi keluarga akan berdampak pada status gizinya. Kecukupan energi dan protein per kapita per hari anak Indonesia terlihat rendah jika dibandingkan Angka Kecukupan Gizi (AKG) yang dianjurkan baik pada anak normal ataupun stunting. Penelitian sebelumnya yang melihat prevalensi stunting pada balita di kota Medan (skema PDP tahun 2017) juga menunjukkan hasil bahwa asupan energi pada balita stunting lebih rendah dari AKG. Statistik kesejahteraan masyarakat Kab. Langkat mencatat pengeluaran rumah tangga untuk makanan di Kabupaten Langkat tahun 2018 pada kelompok 40 persen terbawah sebesar 308.580 rupiah per bulan dengan rata-rata jumlah anggota keluarga 4 orang. Oleh karena itu perlu untuk mengkaji bagaimana ketahanan pangan rumah tangga Balita 0-59 bulan di desa Secanggang sebagai desa prioritas stunting untuk mengetahui ketersediaan pangan yang cukup baik jumlah maupun mutunya, aman, beragam, bergizi, merata, dan terjangkau untuk dapat hidup sehat, aktif dan produktif serta berkelanjutan sebagai salah satu upaya intervensi sensitif penanggulangan stunting

\section{METODOLOGI PENELITIAN}

Penelitian menggunakan pendekatan cross sectional yang dilakukan di Desa Secanggang Kecamatan Secanggang Kabupaten Langkat dengan jumlah balita 0-59 bulan adalah 134 orang. Sampel dihitung menggunakan rumus Slovin dan jumlah sampel yang diperoleh adalah 45 orang. Data yang digunakan adalah data primer yang diperoleh melalui wawancara dan pengukuran langsung. Data stunting diperoleh menggunakan indikator TB/U dan ketahanan pangan diukur menggunakan USHFSS. Analisis data dilakukan bertahap meliputi analisis univariat dan bivariat. Analisis univariat untuk mendeskripsikan karakteristik responden, stunting dan ketahanan pangan di Desa Secanggang. Analisis bivariat menggunakan uji chi square untuk melihat hubungan ketahanan pangan dan stunting.

\section{HASIL DAN PEMBAHASAN}

\section{Karakteristik Balita 0-59 Bulan}

Karakteristik balita 0-59 bulan berdasarkan jenis kelamin didominasi oleh perempuan $62,2 \%$ dan laki-laki 37,8\%. Secara lengkap karakteristik responden disajikan pada Gambar 1.

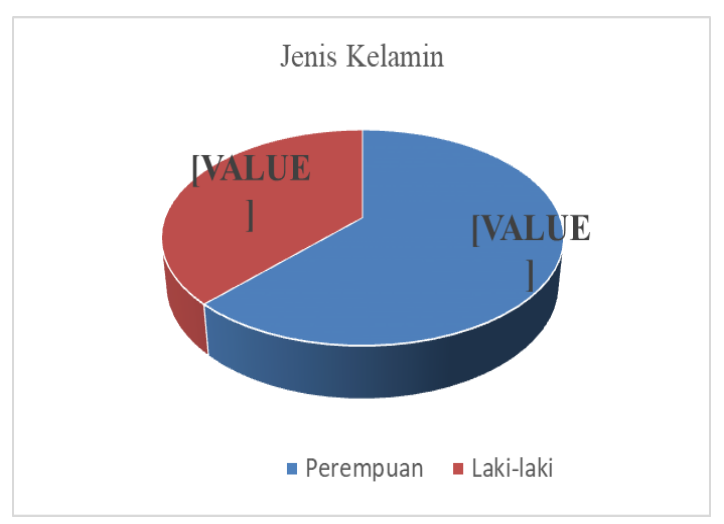

Gambar 1 


\section{Stunting dan Ketahanan Pangan}

Penelitian mengumpulkan 45 data status gizi balita usia 0-59 bulan dan ketahanan pangan rumah tangga (RT). Diketahui bahwa $42,2 \%$ balita mengalami stunting atau sebanyak 19 orang balita berdasarkan indikator TB/U. Data ketahanan pangan rumah tangga (RT) melaporkan bahwa 55,6\% RT tergolong tidak aman pangan dan 44,4\% tergolong ketahanan pangan, secara lengkap data stunting dan ketahanan pangan rumah tangga (RT) balita 0-59 bulan disajikan pada Gambar 2 dan Gambar 3.
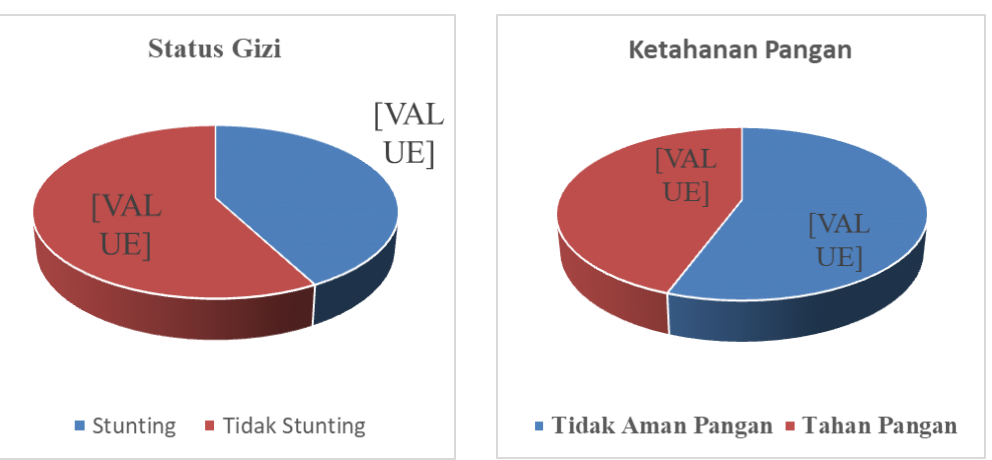

Hasil analisis hubungan ketahanan pangan dan stunting pada balita 0-59 bulan diperoleh bahwa ada sebanyak 15 balita $(60,0 \%)$ stunting pada rumah tangga dengan kategori ketahanan pangan yang tidak aman pangan. Hasil uji statistik diperoleh nilai $p=0,017$ maka dapat disimpulkan ada perbedaan proporsi kejadian stunting balita 0-59 bulan pada rumah tangga dengan ketahanan pangan dan tidak aman pangan.

Tabel 1. Ketahanan Pangan Rumah Tangga (RT) dan Stunting Pada Balita 0-59 Bulan

\begin{tabular}{|c|c|c|c|c|c|c|c|}
\hline \multirow{3}{*}{ Variabel independent } & \multicolumn{4}{|c|}{$\begin{array}{c}\text { Variabel dependent } \\
\text { (Stunting) }\end{array}$} & \multirow{2}{*}{\multicolumn{2}{|c|}{ Total }} & \multirow{3}{*}{ p-Value } \\
\hline & Tidak & & & & & & \\
\hline & $\mathbf{n}$ & $\%$ & $\mathbf{n}$ & $\%$ & $\mathbf{n}$ & $\%$ & \\
\hline \multicolumn{8}{|l|}{ Ketahanan Pangan RT } \\
\hline Ketahanan Pangan & 16 & 80,0 & 4 & 20,0 & 20 & 100 & 0,017 \\
\hline Tidak Aman Pangan & 10 & 40,0 & 15 & 60,0 & 25 & 100 & \\
\hline
\end{tabular}

Hasil penelitian menunjukkan bahwa sebagian dari rumah tangga (RT) responden telah mengalami tidak aman pangan (55,6\%). Sebanyak 15 balita stunting (60,0\%) ditemukan pada rumah tangga dengan kategori ketahanan pangan yang tidak aman pangan. Hasil uji chi square menunjukkan ketahanan pangan RT memiliki hubungan yang signifikan dengan kejadian stunting pada balita 0-59 bulan $(p=0,017)$ (Tabel 1). Hasil penelitian ini sejalan dengan penelitian Masrin dkk. tahun 2014 yang melaporkan bahwa ada hubungan yang signifikan antara ketahanan pangan rumah tangga dengan kejadian stunting pada baduta usia 6-23 bulan di Kecamatan Sedayu Bantul Yogyakarta (Masrin, 2014). Penelitian Utami tahun 2015 juga melaporkan hal yang sama bahwa ketahanan pangan rumah tangga merupakan risiko kejadian pendek pada balita dimana anak balita dengan keluarga dengan ketahanan pangan nya tidak baik memiliki risiko sebesar 10,9 kali anak balita nya menjadi pendek setelah dikoreksi oleh 
usia anak, berat lahir, konsumsi ASI, penggunaan dot, keragaman makanan, usia ibu, pendidikan ibu, pengetahuan gizi ibu, praktik higiene makanan, pendidikan ayah dan pekerjaan ayah (Utama, 2015).

Rumah tangga dengan ketahanan pangan tergolong tidak aman pangan dapat berdampak pada permasalahan gizi dan kesehatan bagi anggota rumah tangga terutama kelompok rentan diantaranya balita. Balita yang berada pada kondisi rumah tangga tahan pangan akan mempunyai akses yang baik terhadap pangan, baik mutu maupun jumlahnya dan ini akan berdampak pada terpenuhinya kebutuhan gizi balita sehingga tercapai status gizi yang optimal. Berbeda dengan balita stunting yang tidak aman pangan memiliki akses pangan yang kurang sehingga porsi makan dikurangi untuk berbagi dengan anggota keluarga lainnya. Hal ini didukung data desa Secanggang yang di publish di Secanggang Dalam Angka bahwa 0,24\% RT di desa ini tergolong sebagai keluarga Prasejahtera (BPS Langkat, 2018).

Balita memiliki akses kurang terhadap pangan jika kualitas dan kuantitas komposisi menu hariannya kurang lengkap serta frekuensi lauk nabati yang lebih dominan. Sejalan dengan hal ini maka rumah tangga yang tidak aman pangan, komposisi menu tidak bergizi, tidak seimbang dan tidak bervariasi secara kualitas dan kuantitas dapat menyebabkan keterlambatan pertumbuhan dan kekurangan gizi balita (Adriani \& Wirjatmadi, 2012).

Penjelasan diatas menunjukkan bahwa semakin baik ketahanan pangan rumah tangga maka akan semakin baik asupan makanan balita nya. Hal ini karena akses RT terhadap pangan semakin baik sehingga kemampuan keluarga menyediakan makanan guna memenuhi kebutuhan gizi anak dan anggota keluarga lainnya semakin baik. Dengan ketahanan pangan rumah tangga yang semakin baik maka penanganan stunting akan lebih mudah mencapai target

\section{KESIMPULAN}

Sebanyak $60,0 \%$ balita usia 0-59 bulan stunting ditemukan pada rumah tangga dengan kategori ketahanan pangan yang tidak aman pangan. Penelitian menyimpulkan bahwa ketahanan pangan rumah tangga memiliki hubungan yang signifikan dengan kejadian stunting pada balita $0-59$ bulan.

\section{DAFTAR PUSTAKA}

Adriani M., Wirjatmadi B. (2012). Pengantar Gizi Masyarakat. Jakarta: Kencana Predana Media Group.

BPS Kabupaten Langkat. (2018). Statistik Kesejahteraan Rakyat Kabupaten Langkat 2018. Langkat: BPS.,

Fentiana, N., Sinarsih, S. (2018). Prevalensi Stunting Balita di Medan-Indonesia Akibat Defisiensi Asupan Energi: Analisis Faktor Yang Mempengaruhi. Jurnal Masyarakat Khatulistiwa, JKMK 5 (1), 8-14.

Kementerian Kesehatan Republik Indonesia. (2007). Laporan Riskesdas 2007. Jakarta: Kementerian Kesehatan Republik Indonesia, Badan Penelitian dan Pengembangan Kesehatan. 
Kementerian Kesehatan Republik Indonesia. (2010). Laporan Riskesdas 2010. Jakarta: Kementerian Kesehatan Republik Indonesia, Badan Penelitian dan Pengembangan Kesehatan.

Kementerian Kesehatan Republik Indonesia. (2013). Laporan Riskesdas 2013. Jakarta: Kementerian Kesehatan Republik Indonesia, Badan Penelitian dan Pengembangan Kesehatan.

Kementerian Kesehatan. (2017). Hasil Pemantauan Status Gizi (PSG) Tahun 2017. Jakarta: Direktorat Gizi Masyarakat, Direktorat Jenderal Kesehatan Masyarakat.

Masrin, P, Y., Aprilia V., (2014). Ketahanan Pangan Rumah Tangga Berhubungan Dengan Stunting Pada Anak Usia 6-23 Bulan. Jurnal Gizi dan Dietetik Indonesia, 2 (3), 103-115.

Menteri dalam Negeri RI. (2018). Instruksi Mendagri No.440/1959/SJ tahun 2018. Jakarta: Menteri Dalam Negeri, Sekretariat Direktorat Jenderal Bina Pembangunan Daerah.

Tim Nasional Percepatan Kemiskinan. (2018). 160 Kabupaten/Kota Prioritas Dengan Masingmasing 10 Desa Untuk Penanganan Stunting (Kerdil). Jakarta: Kementerian Koordinator Pembangunan Manusia dan Kebudayaan.

Trihono dkk. (2015). Pendek (stunting) di Indonesia, Masalah dan Solusinya. Jakarta: Badan Penelitian dan Pengembangan Kesehatan.

Utama N, H, Sisca D. (2015). Ketahanan Pangan Rumah Tangga Berhubungan Dengan Status Gizi Anak Usia Dibawah Dua Tahun (Baduta) di Kelurahan Kebon Kelapa, Kecamatan Bogor Tengah, Jawa Barat. Jurnal Persegi, 38 (2), 105-114. 